\title{
Sistem Informasi Sekolah Pada Sekolah Dasar Negeri 21 Sungai Geringging Kabupaten Padang Pariaman Berbasis Web
}

\author{
Darmansah $^{1}$, Zulva Suhendro \\ ${ }^{1}$ Program Studi,system Informasi,Institut Teknologi Telkom Purwokerto, \\ ${ }^{2}$ Program Studi, Sistem Informasi,STMIK INDONESIA Padang \\ E-mail: ${ }^{1}$ darmansah@ittelkom-pwt.ac.id ${ }^{2}$ androzulva85@gmail.com
}

\begin{abstract}
ABSTRAK
Sekolah Dasar Negeri 21 Sungai Geringgingmerupakan salah satu instansi pendidikan. Selama ini proses informasi sekolah memang sudah menggunakan komputer, akan tetapi belum menggunakan aplikasi yang bisa merekap semua kegiatan sekolah. Sehingga tentunya dapat memperlambat proses pembuatan laporan. Laporan yang dibutuhkan yaitu laporan data siswa, guru, mata pelajaran, kelas, jadwal pelajaran, nilai, absensi siswa, dan absensi guru. Dilihat dari permasalahan di atas maka dibentuklah sebuah sistem informasi sekolah yang dapat membantu proses pembuatan laporan secara terinci dan efisien. Aplikasi yang digunakan yaitu bahasa pemograman $P H P$ dengan database MySql yang dapat mempermudah petugas dalam mengolah data sekolah. Dengan dibangunnya aplikasi ini, di harapkan semua kendala yang dihadapi dapat teratasi dan dapat meningkatkan kualitas pendidikan yang prima kepada masyarakat.
\end{abstract}

Kata Kunci: Sistem Informasi Sekolah, SD negeri 21 Sungai Geringging, Berbasis Web.

\section{ABSTRACT}

Sekolah Dasar Negeri 21 Sungai Geringgingis an educational institution. During this time the school information process is already using a computer, but has not used an application that can recap all school activities. So of course it can slow down the process of making reports. Reports needed are student data reports, teachers, subjects, classes, lesson schedules, grades, student absences, and teacher absences. Judging from the problems above, a school information system has been formed that can help the process of making detailed and efficient reports. The application used is the PHP programming language with MySql database that can facilitate officers in processing school data. With the construction of this application, it is expected that all obstacles faced can be overcome and can improve the quality of excellent education to the community.

Keyword:School Information System, SD Negeri 21 Sungai Geringging,Web-based.

Author Korespondensi (Darmansah)

Email :darmansah@ittelkom-pwt.ac.id

\section{PENDAHULUAN}

Pembangunan Sistem Informasi Sekolah yang bisa digunakan untuk mempercepat atau mempermudah sekolah dalam pengolahan data siswa, guru yang mencakup pengolahan nilai, penerimaan siswa baru, kegiatan ektrakurikuler, pelanggaran, beasiswa, sehingga dengan adanya Sistem Informasi Sekolah ini dapat mempermudah pekerjaan pada Sekolah tersebut.
Sistem Informasi Sekolah ini, dapat meningkatkan efektifitas dan kinerja sekolah. Karena dengan adanya sistem informasi ini dapat membantu seseorang yang membutuhkan informasi tentang suatu sekolah dapat langsung mengetahuinya tanpa perlu membuang tenaga, waktu, dan biaya untuk datang ke tempat dimana informasi tersebut berada. Untuk mengaksesnya pun tidak memerlukan keahlian khusus karena cara mengoperasikan sangatlah mudah. Hanya dengan mengetik alamat situs yang dituju, lalu melakukan login pada halaman utama, kita bisa 
melihat halaman informasi yang kita tuju dan dalam waktu singkat informasi bisa langsung diperoleh.

Saat ini di SD Negeri 21 Sungai Geringging masih menggunakan sistem manual menggunakan Microsoft Excel dalam menangani pengolahan data siswa, guru yang mencakup pengolahan nilai, penerimaan siswa baru, kegiatan ektrakurikuler, pelanggaran, dan beasiswa sehingga menyulitkan pihak sekolah dalam mengelola data dan membutuhkan banyak waktu.

SD Negeri 21 Sungai Geringging Kabupaten Padang Pariaman sebagai lembaga suatu pendidikan yang selalu mengikuti perkembangan teknologi informasi yang sedang berkembang. Pengolahan data yang selama ini sulit dikerjakan karena menggunakan proses manual yang hanya dibuat pada lembaran kertas atau Microsoft Excel. Permasalahan sering muncul adalah kesalahan sering dilakukan oleh manusia (human error). Permasalahan lain yang muncul adalah seperti penyusunan laporan yang kurang efektif, sulitnya mengumpulkan data yang terpisah, sehingga diharapkan dengan adanya sistem informasi Sekolah ini mudahmudahan dapat mempermudah dan mempercepat pengolahan data siswa, guru di SD Negeri 21 Sungai Geringging Kabupaten Padang Pariaman.

Dilihat dari kenyataan tersebut, diperlukan suatu sarana penunjang yang mampu meningkatkan efektifitas dan efisiensi pengolahan data tersebut, serta memaksimalkan pendidikan dan pengajaran yang ada di SD Negeri 21 Sungai Geringging Kabupaten Padang Pariaman. Sarana ini dibuat dengan basis sistem informasi sehingga dapat digunakan baik di lingkungan sekolah maupun luar sekolah yang bersifatmultiuser.

\section{METODOLOGI}

Adapun metode yang digunakan dalam penelitian ini terdiri dari:

\subsection{Field Research}

Yaitu penelitian yang dilakukan dengan cara mendatangi langsung tempat atau lokasi yang dijadikan sebagai tempat penelitian. Teknik studi lapangan dapat dilakukan dengan cara wawancara (Interview) dengan mengadakan tanya jawab dengan kepala sekolah dalam sistem pengolahan nilai, penerimaan siswa baru, kegiatan ektrakurikuler, pelanggaran, beasiswa. Dan selanjutnya Observasi (observation) yaitu melakukan penelitian dan pengamatan secara langsung mengenai kegiatan dan keadaan SD Negeri 21 Sungai Geringging Kabupaten Padang Pariaman.

\section{2..Library Research}

Yaitu penelitian yang dilakukan dengan cara membaca berbagai literature yang ada hubungannya dengan masalah pengolahan nilai, penerimaan siswa baru, kegiatan ektrakurikuler, pelanggaran, beasiswa pada sekolah, seperti buku-buku sumber, artikelartikel, catatan perkuliahan, majalah serta tulisan-tulisan yang berkaitan dengan permasalahan yang sedang diteliti tentang sistem informasi sekolah.

\subsection{Laboratory Research}

Melakukan penelitian dilabor dengan data yang telah dikumpulkan yaitu data pengolahan nilai, penerimaan siswa baru, kegiatan ektrakurikuler, pelanggaran, beasiswa, yang kemudian diolah dengan menggunakan perangkat keras (hardware) dan perangkat lunak (software) komputer, untuk dapat dilakukan pengujian dan pengimplemetasian hasil program.

\subsection{Systems Development Life Cycle (SDLC)}

SDLC atau System Development Life Cycle atau sering disebut juga System Development Life Cycle adalah proses mengembangkan atau mengubah suatu system perangkat lunak dengan menggunakan modelmodel dan metodologi yang digunakan orang untuk mengembangkan system-system perangkat lunak sebelumnya berdasarkan best practice atau cara-cara yang sudah teruji baik 
[4].Adapun langkah-langkah dari System Development Life Cycle (SDLC) sebagai berikut:

1. Perencanaan Sistem (System Planning) atau Identifikasi Sistem yaitu akan membangun sistem informasi berbasis website yang dapat membantu pihak sekolah, dimana sistem itu dapat diakses dimana saja asalkan terkoneksi pada jaringan internet. Tujuan dibuat sistem ini agar lebih meningkatkan efisiensi serta mempermudah dalam pengolahan penyimpanan data.

2. Analisis Sistem (System Analysis)

Dapat dianalisis dengan analisa sebagai berikut:

1) Pada sistem yang lama penyimpanan data masih menggunakan microsoft excel yang sering terjadi kehilangan data siswa dan guru, dengan adanya sistem yang baru ini penyimpanan data sudah menggunakan database yang sudah dijamin keamanan dan kevalitannya.

2) Pada sistem yang lama pihak sekolah sedikit susah untuk pengolahan data siswa dan guru dengan adanya sistem yang baru ini dapat mempermudah pihak sekolah untuk mengontrol nilai siswa dari guru, absensi siswa dan guru serta mata pelajaran..

3) Pada sistem yang lama guru memberikan data nilai siswa, absensi siswawa dan data pelangaran siswa kepada tata usaha, dengan sistem yang baru ini dapat mempermudah guru dalam memasukan data tersebut dengan cara memasukan langsung melalui sistem yang telah ada.

3. Perancangan Sistem (Design System) yaitu kegiatan pertama yang akan dilakukan yaitu merancang rancangan globalnya yaitu Hipo sistem informasi sekolah, lalu Contex Diargam sistem informasi sekolah, didalamnya ada Data Flow Diagram sistem informasi sekolah dan Entity Relationship Diagram sistem informasi sekolah selanjutnya melakukan rancangan terinci yaitu melakukan Desain Output, input, database, file, proses dan relasi antar file. Semua ini akan menghasilkan sistem informasi sekolah pada SD negeri 21 sungai geringging.
4. Implementasi Sistem (System Implementation) yaitu menjalankan dan menggunakan sistem yang telah selesai dengan input data proses pengolahan data dan penyampaian informasi kepada Kepala sekolah sesuai dengan tujuan sistem [4].

\section{HASIL DAN PEMBAHASAN}

\subsection{Pembahasan}

Berdasarkan permasalahan dan kendala yang terjadi pada sistem yang berjalan selama ini, maka dapat diusulkan suatu sistem yang baru yang dapat memberikan kemudahan dalam melakukan kegiatan pengolahan data untuk menghasilkan laporan yang baik, cepat, dan akurat.

Perancangan sistem informasi Sekolah menggunakan program aplikasi komputer yang dibuat dengan menggunakan bahasa pemrograman $P H P$ sehingga terasa lebih optimal.

Aliran Sistem Informasi (ASI) yang diusulkan memiliki perbedaan dengan aliran sistem informasi yang sedang berjalan. Perbedaannya adalah: 
Tabel 1. Perbanding aliran sistem infromasi yang sedang berjalan dan yang di usulkan.

\begin{tabular}{|c|c|}
\hline $\begin{array}{c}\text { Sistem yang Sedang } \\
\text { Berjalan }\end{array}$ & $\begin{array}{l}\text { Sistem yang } \\
\text { Diusulkan }\end{array}$ \\
\hline $\begin{array}{l}\text { Pengolahan data masih } \\
\text { secara manual }\end{array}$ & $\begin{array}{l}\text { Pengolahandata } \\
\text { sudah } \\
\text { terkomputerisasi } \\
\text { dengan } \\
\text { menggunakan } \\
\text { Sistem Informasi } \\
\text { Sekolah Pada SD } \\
\text { Negeri } 21 \text { Sungai } \\
\text { Geringging } \\
\text { Kabupaten } \\
\text { Padang Pariaman } \\
\text { Berbasis Web }\end{array}$ \\
\hline $\begin{array}{lr}\text { Penyimpanan data } & \text { masih } \\
\text { menggunakan } & \text { media } \\
\text { penyimpanan } & \text { seperti } \\
\text { buku Catatan } & \text { biasa, } \\
\text { sehingga data } & \text { kurang } \\
\text { terjamin } & \end{array}$ & \begin{tabular}{l}
\multicolumn{3}{l}{ Penyimpanan } \\
data sudah \\
menggunakan \\
database. \\
Sehingga lebih \\
teratur dan aman \\
walau sudah \\
disimpan dalam \\
waktu yang lama
\end{tabular} \\
\hline $\begin{array}{l}\text { Tidak adanya laporan } \\
\text { pengolahan data yang } \\
\text { diingginkan pada waktu } \\
\text { tertentu. }\end{array}$ & $\begin{array}{lr}\text { Laporan } & \text { dapat } \\
\text { dapat } & \text { diproses } \\
\text { kapan } & \text { saja } \\
\text { diperlukan } & \text { dan } \\
\text { informasi } & \text { yang } \\
\text { dihasilkan } & \text { juga } \\
\text { dapat } & \text { di } \\
\text { tampilkan } & \text { secara } \\
\text { langsung } & \\
\end{array}$ \\
\hline $\begin{array}{l}\text { Kesulitan } \\
\text { mendeteksi kesalahan } \\
\text { dalam pengolahan data } \\
\text { siswa ataupun guru. }\end{array}$ & $\begin{array}{l}\text { Data dapat } \\
\text { diperbaiki } \\
\text { sewaktu-waktu } \\
\text { apabila } \\
\text { dibutuhkan }\end{array}$ \\
\hline
\end{tabular}

Perancangan sistem informasi ini terdiri atas rancangan global yaitu Hearchy Plus Input Process Output (HIPO), Context Diagram (CD)Data Flow Diagram (DFD), Entity Relationship Diagram (ERD ).

a. Rancangan Global

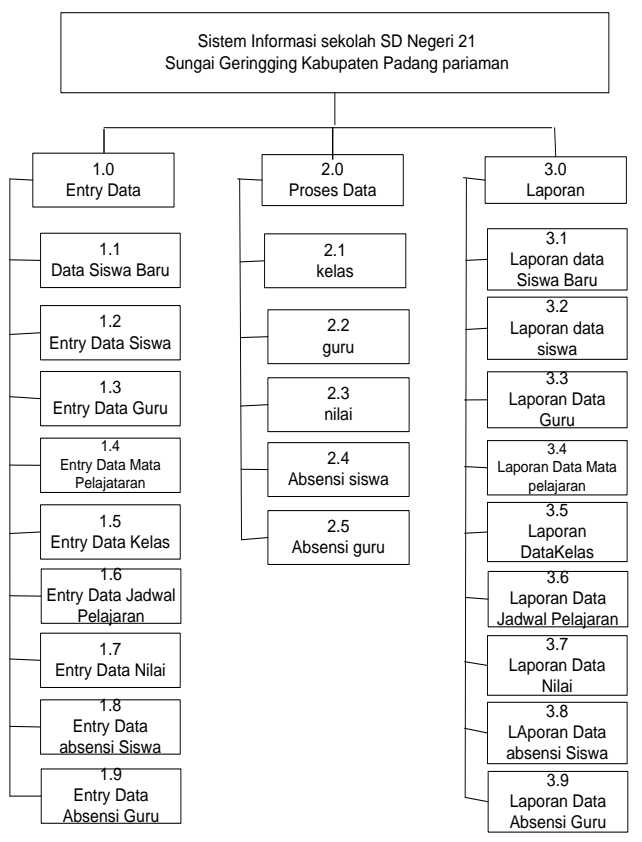

Gambar 1. Hearchy Plus Input Process Output (HIPO)

2) Context Diagram (CD)

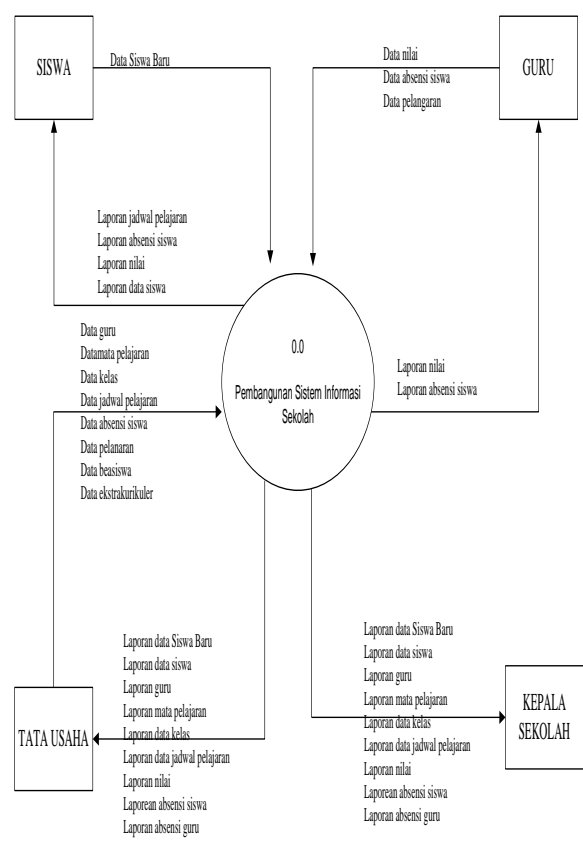

Gambar 2. Context Diagram (CD)

3) Data Flow Diagram (DFD)

1) Hearchy Plus Input Process Output (HIPO) 


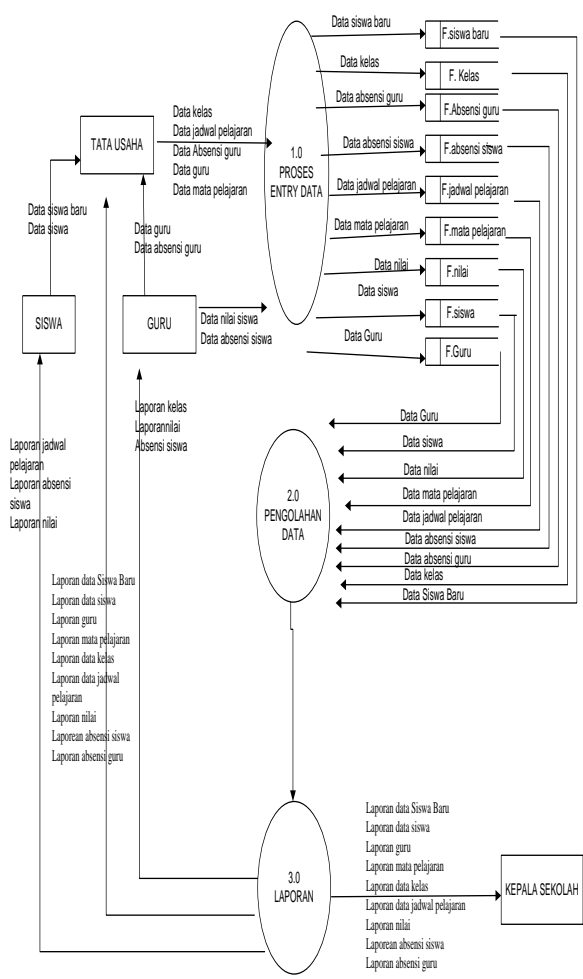

Gambar 3. Data Flow Diagram (DFD)

\section{4) Entity Relationship Diagram (ERD).}

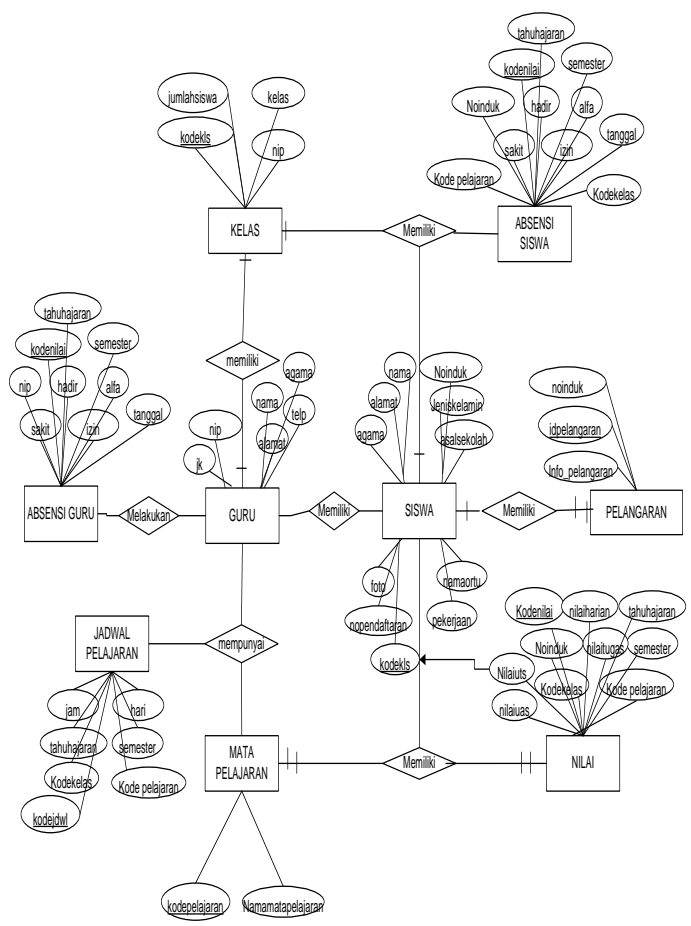

Gambar 4. Entity Relationship Diagram (ERD).

b. Hasil

Sistem Informasi sekolah pada SD Negeri $21 \quad$ Sungai Geringgingmerupakan sistem aplikasi yang dapat digunakan oleh tata usaha dalam melakukan pegolahan data. Rancangan sistem informasi sekolah ini terdari dari Input, Proses dan Output. Adapun penjelasannya seperti berikut ini:

\section{1) Input}

Form input merupakan form masukan data yang dibutuhkan oleh tata usaha dan guru untuk pengolahan data. Form input terdiri dari input data siswa baru, input data siswa, input data guru, input data mata pelajaran, input data kelas, input data jadwal pelajaran, input data nilai, input data data absensi siswa dan input data absensi guru. Adapun bentuk inputan terdapat pada Sistem Informasi sekolah dapat dilihat pada gambargambar berikut ini:

(1). Input Data siswa Baru

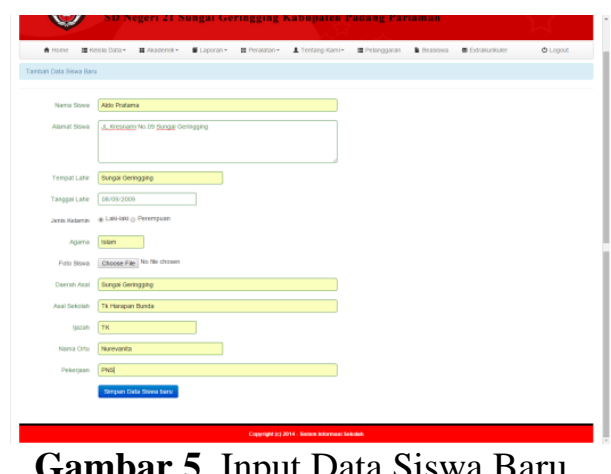

Gambar 5. Input Data Siswa Baru 
(2). Input Data Siswa

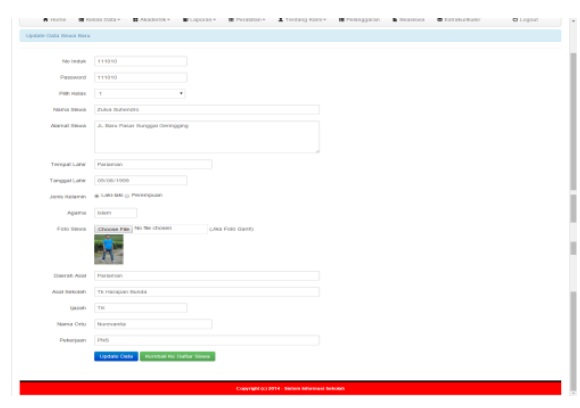

Gambar 2. Input Data Siswa

(3). Input Data Guru

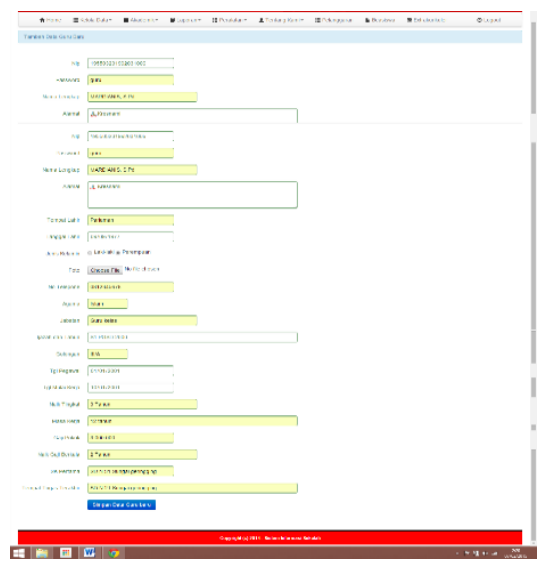

Gambar 6. Input Data Guru

(4). Input Data Mata Pelajaran

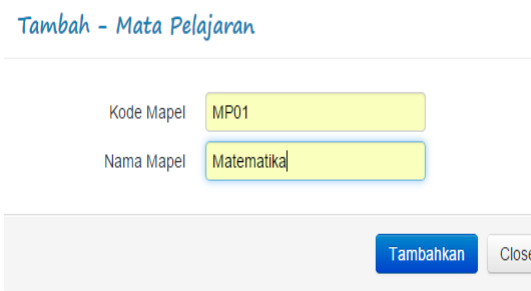

Gambar 7. Input Data Mata Pelajaran

(5). Input Data Kelas

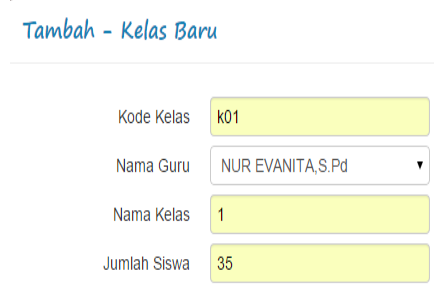

Tambahkan

Gambar 8. Input Data Kelas

(6). Input Data Jadwal Pelajaran

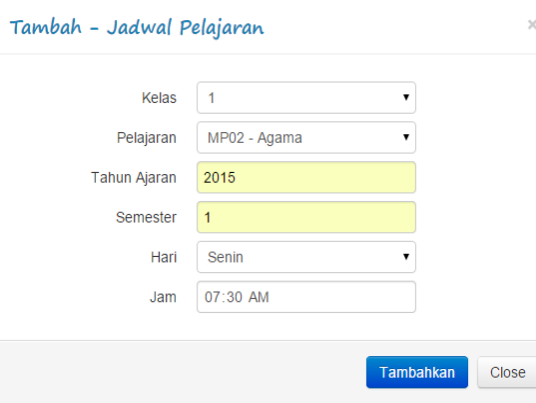

Gambar 9. Input Data Jadwal Pelajaran

(7). Input Data Nilai

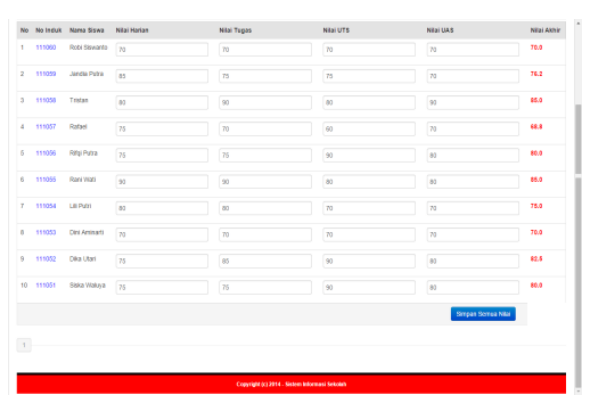

Gambar 10. Input Data Nilai

(8). Input Data Absensi Siswa

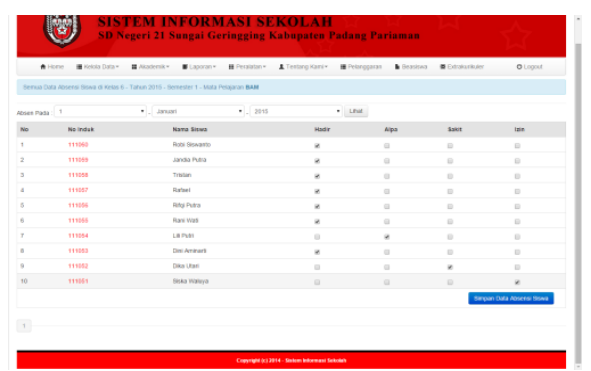

Gambar 11. Input Data Absensi Siswa 


\section{(9). Input Data Absensi Guru}

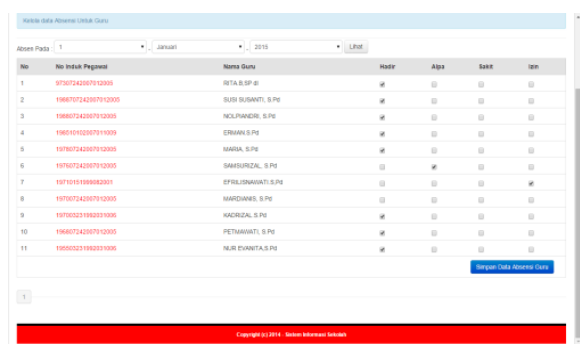

Gambar 12. Input Data Absensi Guru

\section{2) Proses}

Pada form proses pengolahan data terdapat proses pencarian data absensi siswa dan guru. Pada pencarian data sistem infoormasi sekolah, tata usaha mengentrikan perhari dan perbulan pada Sistem Informasi Sekolah pada SD Negeri 21 Sungai Geringgingsebagai berikut:

(1). Proses Pencarian Data Absensi Siswa

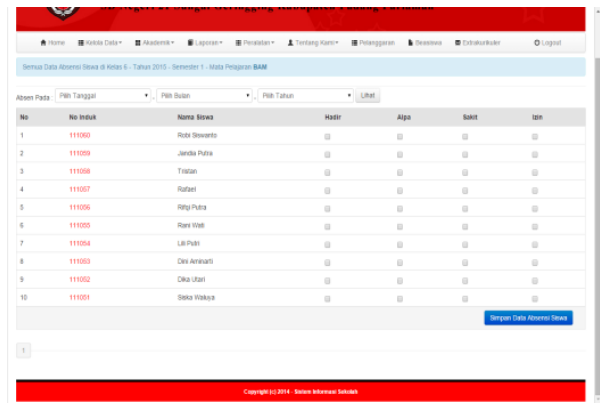

Gambar 13. Proses Pencarian Data Absensi Siswa

(2). Proses Pencarian Data Absensi Guru

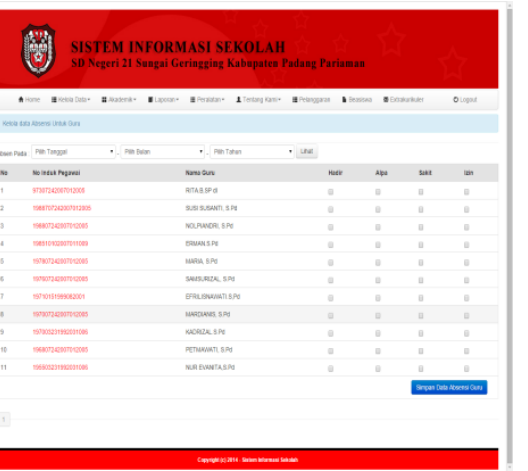

Gambar 14. Proses Pencarian Data Absensi Guru

\section{3) Output}

Form output merupakan jembatan untuk menghasilkan dokumen yang ingin dicetak. Form outputlapran data siswa, laporan dta siswa baru, laporan data guru, laporan dta absensi guru, mata pelajaran, jadwal poelajaran, nilai. Adapun bentuk laporan-laporan yang terdapat pada sistem informasi sekolah pada SD Negeri21 Sungai Geringging berikut ini: 
(1). Laporan Data Siswa

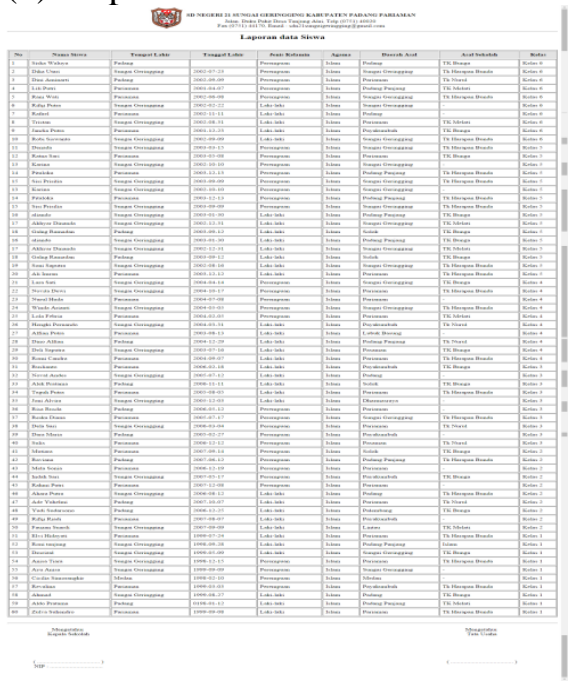

Gambar 15. Laporan Data Siswa

(2). Laporan Guru

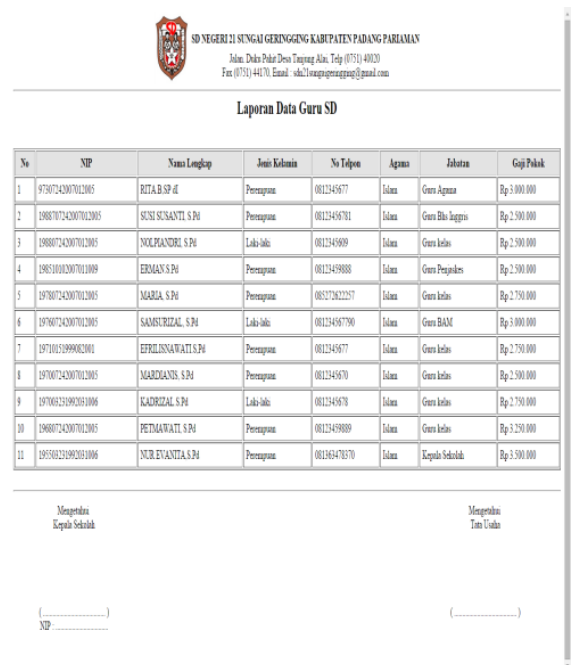

Gambar 16. Laporan Data Guru

(3). Laporan Mata Pelajaran

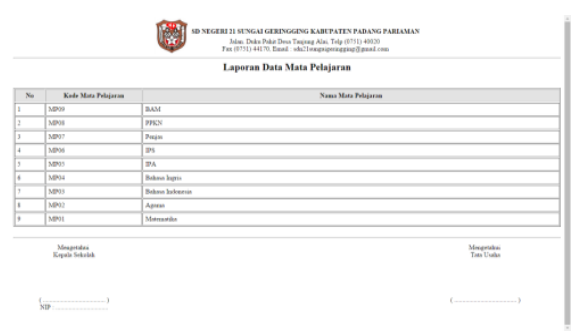

Gambar 17. Laporan Mata Pelajaran
(4). Laporan Data Kelas

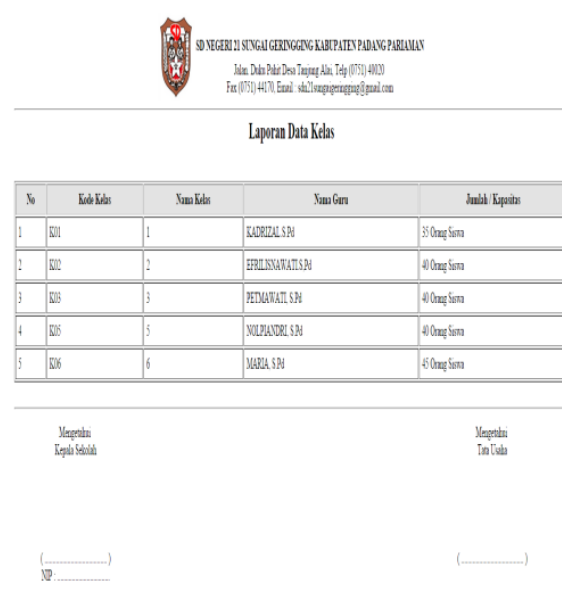

Gambar 18. Laporan Data Kelas

(5). Laporan Data Jadwal Pelajaran

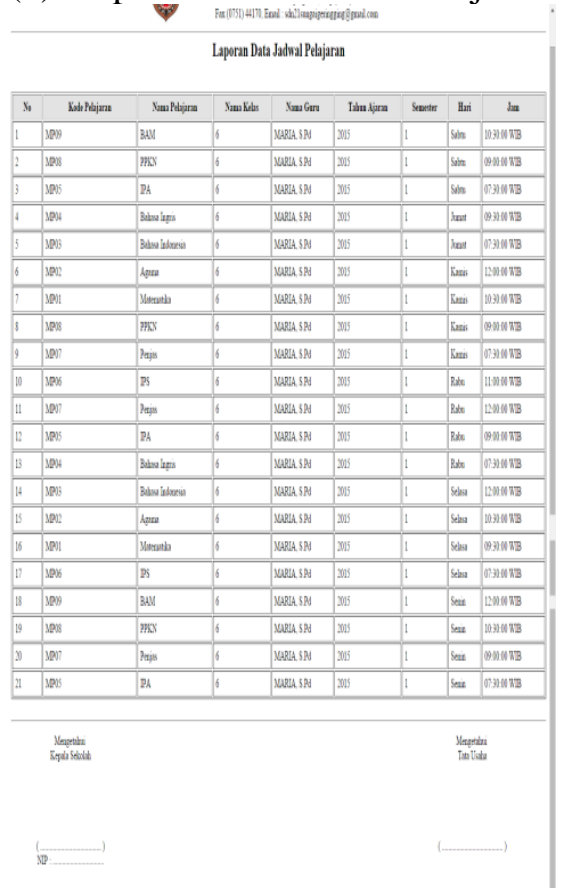

Gambar 19. Laporan Data Jadwal Pelajaran 
(6). Laporan Data Nilai

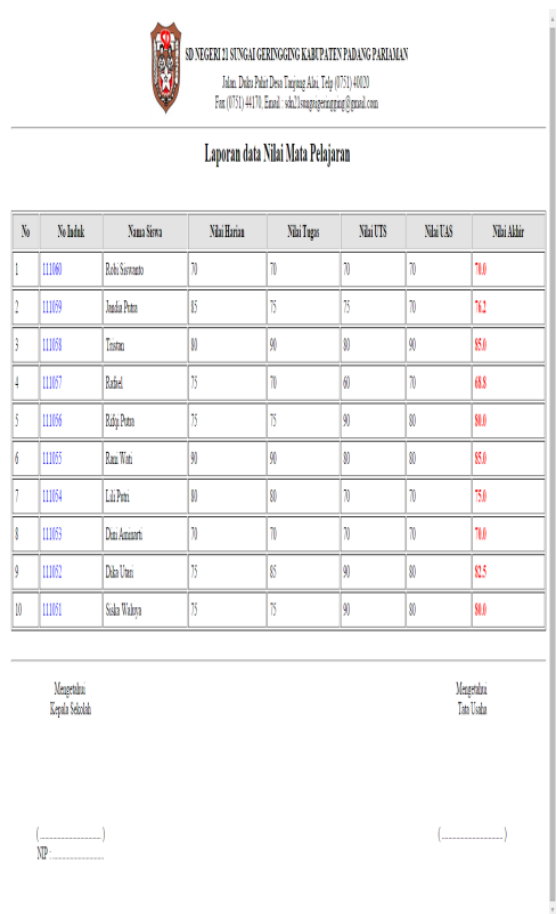

Gambar 20. Laporan Data Nilai

\section{(7). Laporan Absensi Data Siswa}

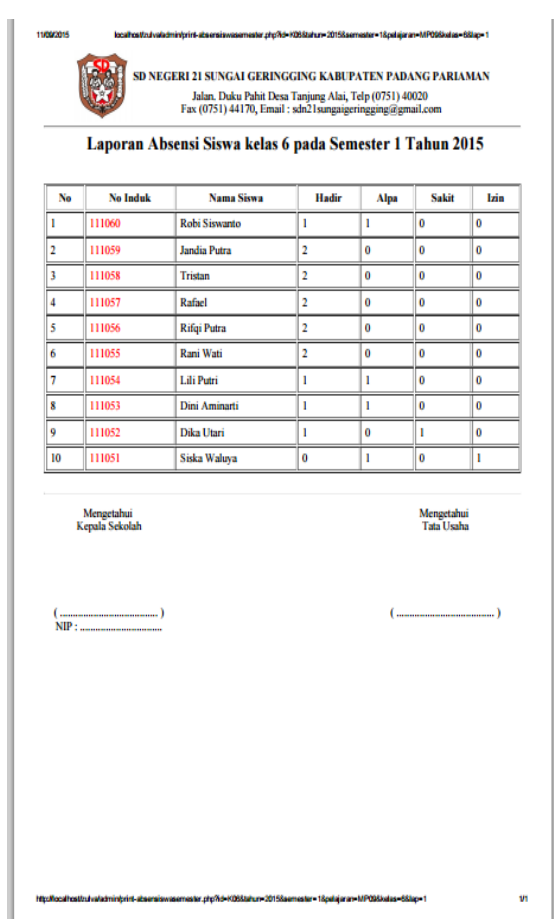

Gambar 21. Laporan Data Absensi
Siswa

(8). Laporan Data Absensi Guru

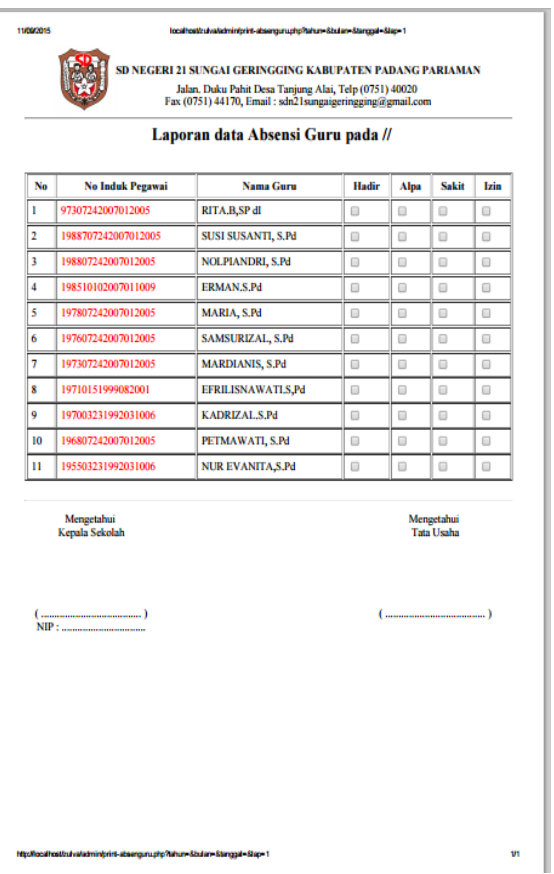

Gambar 22. Laporan Data Absensi Guru

\section{SIMPULAN DAN SARAN}

Berdasarkan pembahasan yang telah dilakukan pada bab-bab sebelumnya serta analisa yang telah dilakukan terhadap sistem yang berjalan, maka penulis dapat mengambil kesimpulan sebagai berikut ini :

1. Dengan menggunakan sistem informasi sekolah memudahkan tata usaha dan guru dalam mengolah data.

2. File-file yang berhubungan dengan data siswa dan guru tersusun dengan baik dan memudahkan siswa, guru dan tata usaha mendapatkan informasi yang sewaktuwaktu dibutuhkan.

3. Dengan adanya sistem informasi sekolah akan lebih membantu dalam menampilkan Informasi.

Setelah mengemukakan beberapa kesimpulan dari keseluruhan isi skripsi ini maka dapat dikemukakan saran-saran sebagai berikut :

1. Penggantian sistem yang lama dengan sistem yang baru memerlukan waktu, serta periode pengenalan sistem dilakukan secara 
bersamaan, maka pada saat penerapan sistem yang baru benar-benar siap untuk diterapkan.

2. Dalam proses sistem baru ini, sistem lama sebaiknya tetap berjalan seperti biasa hingga sistem baru tersebut siap untuk menggantikan sistem yang lama.

3. Hendaknya ada suatu pelatihan atau training yang dilakukan kepada staf pelayanan tentang penggunaan sistem, sehingga sesuai dengan hasil yang diharapkan nantinya.

Sistem informasi sekolah yang diusulkan memiliki keuntungan di dalam kecepatan pengolahan data dan keakuratan yang lebih terjamin, penyajian informasi lebih cepat dan media menyimpan yang lebih baik.

\section{REFERENSI}

[1] Fathansyah, Basis Data. Bandung: informatika, 2012.

[2] Jogiyanto, Sistem Teknologi Informasi. yogyakarta: Andi Offset, 2009.

[3] Kusrini, Tuntunan Praktis Membangun Sistem Informasi Akuntansi Dengan Visual Basic dan Microsoft SQL Server. yogyakarta: Andi Offset, 2007.

[4] Rosa, Rekayasa Perangkat Lunak Terstruktur dan Berorientasi Objek. Bandung: informatika, 2013.

[5] Ryanto, Membuat Aplikasi Mini Market Integrasi Barcode Reader dengan PHP dan MySql. yogyakarta: Gaya Media, 2014.

[6] Rusdiana, Sistem Informasi Manajemen. Bandung: Pustaka Setia, 2014.

[7] Supardi, Semua Bisa Jadi Programer Visual Basic FoxPro 9.0. Jakarta: Alex Media Kompotindo, 2010.

[8] Tata Sutabri, Konsep Sistem Informasi. yogyakarta: Andi Offset, 2012.

[9] Sutanta, Basis Data Dalam Tinjauan Konseptual. yogyakarta: Andi Offset, 2011.

[10] Wardana, Dasar Dasar PHP dan
Software Pendukungnya. yogyakarta: Andi Offset, 2010. 
